\title{
Accommodation of Religion Thirty Years On
}

\section{Citation}

Mark V. Tushnet, Accommodation of Religion Thirty Years On, 38 Harv. J. L. \& Gender 1 (2015).

\section{Published Version}

http://harvardjlg.com/wp-content/uploads/2015/01/Accommodation-of-Religion-Thirty-YearsOn.pdf

\section{Permanent link}

http://nrs.harvard.edu/urn-3:HUL.InstRepos:16217277

\section{Terms of Use}

This article was downloaded from Harvard University's DASH repository, and is made available under the terms and conditions applicable to Other Posted Material, as set forth at http:// nrs.harvard.edu/urn-3:HUL.InstRepos:dash.current.terms-of-use\#LAA

\section{Share Your Story}

The Harvard community has made this article openly available.

Please share how this access benefits you. Submit a story.

\section{Accessibility}




\title{
ACCOMMODATION OF RELIGION THIRTY YEARS ON
}

\author{
MARK TushneT*
}

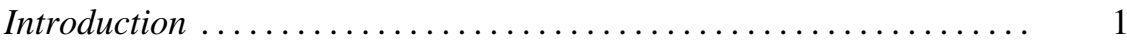

I. The History of Accommodation of Religion ............ 3

A. The Background of Accommodation of Religion ....... 3

B. Mc Connell's Contribution ...................... 5

C. Criticisms of Accommodation of Religion ............ 8

D. The Legacy of Accommodation of Religion........... 13

II. The Contemporary Political Economy of Statutory Accommodations .............................. 13

A. Targeted and General Accommodations ............ 14

B. Substantive Policies and Their Supporters ........... 18

1. Accommodations for Traditional Police Power

Regulations and Progressive-era and New Deal

Legislation ................................. 18

2. Contemporary Accommodations for the Modern

Equality Agenda........................... 19

C. Summary on the Political Economy of

Accommodations ......................... 20

III. Pro-Religion Strict Separation.................... 22

A. The Components of Pro-Religion Strict Separation ..... 23

1. Corruption of Religion .................... 24

2. The Two Sovereigns.................... 27

3. Third-Party Effects on Other Religious Persons.... 29

B. Pro-Religion Strict Separation and an Alternative Mode of Protecting Religious Practices ................. 31

Conclusion ..................................... $\quad 32$

\section{INTRODUCTION}

In 1985, a young academic at the University of Chicago Law School published his first major law review article. Michael McConnell's Accommodation of Religion ${ }^{1}$ offered a new way of thinking about the Religion Clauses of the First Amendment and reshaped academic understanding of the entire

* William Nelson Cromwell Professor of Law at Harvard Law School. J.D. Yale Law School, M.A. Yale University. I thank Nomi Stolzenberg, Douglas NeJaime, Nan Hunter, and Louise Melling for their work in organizing the Harvard Law School symposium, "Religious Accommodation in the Age of Civil Rights," at which an early version of this Article was presented.

1 Michael McConnell, Accommodation of Religion, 1985 Sup. Cт. Rev. 1 [hereinafter McConnell, Accommodation of Religion]. 
range of issues under those clauses. ${ }^{2}$ For about twenty years after the article was published, a reasonably strong consensus supported some version of the accommodation principle, which is that governments can, and perhaps sometimes must, adjust their general programs to take into account the fact that such programs sometimes have adverse effects on those with specific religious beliefs. ${ }^{3}$ Over the past several years, though, this consensus has dissolved, as Paul Horwitz has observed. ${ }^{4}$ Disagreement has invaded the domain of consensus in large part because it now appears that religious believers operating ordinary businesses might have credible claims that they are entitled to exemptions from general anti-discrimination laws protecting women and LGBT people, if their religious beliefs counsel them to deny services to members of those protected classes (on the ground, for example, that facilitating the commercial transactions of members of those classes implicates the believers in evil practices, as when a caterer refuses for religious reasons to supply its services to those celebrating a same-sex marriage in states where such marriages are lawful).

This Article examines Accommodation of Religion in three Parts, with the aim first of understanding why the consensus dissolved and then of offering a novel, even idiosyncratic, defense of the anti-accommodation position. Part One describes the state of the theory of the Religion Clauses when McConnell wrote his article and the arguments McConnell made. It then concludes with some criticisms of his argument, some of which became apparent only after important judicial and legislative developments post-dating the article. Part Two describes the contemporary political environment in which questions of accommodation arise, emphasizing both that the types of accommodations of interest have changed significantly since McConnell wrote and that the subject matter of the legislation for which accommodations are sought has also changed. Both changes make the politics associated

${ }^{2}$ I rely here mostly on my participation in the community of scholars of the Religion Clauses, but a citation count is suggestive of the article's influence in the field. A Lexis search in the "secondary literature" database conducted on Oct. 4, 2014 found 440 citations for "McConnell w/3 'accommodation of religion" " (some of which were citations to a follow-up article he wrote), 159 for "Greenawalt w/3 'religion and the Constitution"” (searching for citations to Kent Greenawalt's important book), and 106 for "Tushnet w/3 'the Constitution of religion'" (searching for citations to my article of that title, published a few years earlier than McConnell's).

${ }^{3}$ See Michael McConnell, Free Exercise Revisionism and the Smith Decision, $57 \mathrm{U}$. ChI. L. Rev. 1109, 1109 (1990) [hereinafter McConnell, Free Exercise] ("For decades, the Free Exercise Clause of the First Amendment was largely uncontroversial."). There was some disagreement around the edges over whether accommodations could be devised by the courts as a matter of constitutional requirement, or whether they could be devised only by legislatures. See Emp't Div. v. Smith, 494 U.S. 872, 890 (1990) (the Supreme Court rejected a comprehensive version of the first position in Smith, id. at 887-89, while leaving open the possibility of some narrow, judicially devised accommodations, $i d$. at 881). For a more extended discussion, see infra text accompanying notes $52-55$.

${ }^{4}$ Paul Horwitz, Faculty Case Comment, The Hobby Lobby Moment, 128 Harv. L. REv. 154, 154-155 (2014). 
with accommodations much more contentious than they were a generation ago. Finally, Part Three offers a challenge to the entire idea of accommodation of religion, which I label "pro-religion strict separation." That challenge rests on two central concerns: religion's susceptibility to corruption by government and the claim that God is sovereign over both the religious and the secular domains. A brief conclusion returns to Accommodation of Religion and, while emphasizing its enduring contribution, speculates that it may no longer be as suitable a candidate for a master theory of the Religion Clauses as it once was.

\section{The History of AcCommodation of Religion}

\section{A. The Background of Accommodation of Religion}

At the time McConnell wrote, scholars and judges took, roughly speaking, one of three general approaches to the Religion Clauses. First, some treated Religion Clause cases as raising questions about how a complicated set of constitutional values could be best advanced-optimized along many dimensions-by specific resolutions. ${ }^{5}$ Decisions would be responsive to subtle variations in factual circumstances. So, for example, a program that set aside time for public school students to attend classes in religious instruction at their schools, if they wanted to do so, and kept other students in their regular classrooms could be treated differently from other released time programs where the students participating in classes in religious instruction were sent off the school grounds. ${ }^{6}$

Second, there was a badly specified approach typically called strict separation. ${ }^{7}$ Strict separation was said to allow no interaction whatsoever between government and religion. As long as the approach focused on classical establishments of religion, in which the government provided direct financial support to religious institutions, strict separation was easy to understand. The strict separation approach could also deal with programs of denominational preference, such as promotion of Christian education in the public

\footnotetext{
${ }^{5}$ Kent Greenawalt was and remains the leading expositor of this approach. His views are summarized in Kent Greenawalt, Religion and the Constitution: Free ExerCISE AND FAIRNESS (2006).

${ }^{6}$ Compare McCollum v. Bd. of Educ., 333 U.S. 203, 212 (1948) (invalidating a released time program where the religious classes were conducted in the public schools), with Zorach v. Clauson, 343 U.S. 306, 315 (1952) (finding constitutionally permissible a released time program where the religious classes were conducted outside the school building).

${ }^{7}$ The majority and dissenting opinions in Everson v. Board of Education, 330 U.S. 1 (1947), both offer versions of strict separation. See id. at 16 (Black, J., for the majority) ("In the words of Jefferson, the clause against establishment of religion by law was intended to erect 'a wall of separation between church and State." () (quoting Reynolds v. United States, 98 U.S. 145, 164 (1978)); id. at 31-32 (Rutledge, J., dissenting) ("The Amendment's . . . object . . . was to create a complete and permanent separation of the spheres of religious activity and civil authority .....).
} 
schools, and government support for religion in general, which could be taken to include some forms of symbolic support for religion, such as the insertion of the phrase "under God" in the Pledge of Allegiance. However, strict separation foundered on a series of problems. Some strict separationists believed that the government could not provide even indirect financial support to religious institutions, such as through the provision of general social services. ${ }^{8}$ That position might make some sense with respect to what might be called novel services, such as the provision of transportation for students to religiously affiliated schools, ${ }^{9}$ but, as Justice Black pointed out, it was hard to reconcile with provision of services like policing (including directing traffic near religiously affiliated schools) and fire protection. ${ }^{10}$ And statutory accommodations of religious belief, such as the exemption of conscientious objectors from military conscription, were plainly inconsistent with strict separation; these accommodations provided something to those who held specific religious beliefs that was unavailable to those holding other beliefs, which was a quintessential breach of strict separation. In my view, by 1985, "strict separation" had become more a public relations phrase than a coherent doctrine.

Finally, Philip Kurland offered an elegant and comprehensive approach, labeled "strict neutrality." ${ }_{11}$ Today we would call it strict formal neutrality. ${ }^{12}$ Kurland argued that "government cannot utilize religion as a standard for action or inaction because [the Religion Clauses] prohibit classification in terms of religion either to confer a benefit or to impose a burden." 13 Thus, governments could not make reference to religion either to burden or to benefit it, which made classical establishments of religion unconstitutional. But, general legislation that made no reference to religion was constitutionally permissible, even if the legislation provided disproportionate benefits to religion, as in the school transportation case, ${ }^{14}$ or imposed disproportionate burdens on it. These principles meant that accommodations posed a problem for Kurland. ${ }^{15}$ Statutory accommodations of religion did refer on their face to

${ }^{8}$ See Everson, 330 U.S. at 47-48 (Rutledge, J., dissenting).

${ }^{9}$ See id. at 44-45.

${ }^{10} \mathrm{Id}$. at 17 (majority opinion).

${ }^{11}$ Philip Kurland, Of Church and State and the Supreme Court, 29 U. CHI. L. REv. 1 (1961). The article consists of a long survey of every Supreme Court dealing with religion up to 1961, from which Kurland infers the principle of strict neutrality-which is indeed compatible with those decisions. Id.

${ }^{12}$ See McConnell, Accommodation of Religion, supra note 1, at 9 (flagging the distinction "between facial neutrality and neutrality in result"). For the term "formal neutrality," see Douglas Laycock, Formal, Substantive, and Disaggregated Neutrality Toward Religion, 39 DePAul L. Rev. 993, 999 (1990) (attributing the "formal neutrality" position to Kurland).

${ }^{13}$ Kurland, supra note 11 , at 6.

${ }^{14}$ Everson, 330 U.S. 1.

${ }^{15}$ For McConnell's criticisms of Kurland, see McConnell, Accommodation of Religion, supra note 1, at 8 ("Not only would benign accommodations to religion . . . be impermissible, but the government could not deny aid to an otherwise eligible organization merely because it is religious."). 
religion and provided benefits to the accommodated entities and so would not be permitted by Kurland's approach. ${ }^{16}$ And, in the era of expanding constitutional rights, claims that certain statutes imposed disproportionate burdens on religion came to be heard with a more sympathetic ear. ${ }^{17}$ The Court responded to those claims by generating the law of constitutionally mandatory accommodations, which began with Sherbert v. Verner, ${ }^{18}$ sometimes requiring accommodations for generally applicable statutes that imposed disproportionate adverse effects on religious believers. ${ }^{19}$

\section{B. McConnell's Contribution}

Then came McConnell. Like Kurland, he argued that the Religion Clauses should be read as a unified whole ${ }^{20}$, "animat[ed]" by religious liberty, the "main components" of which are "the autonomy of religious institutions, individual choice in matters of religion, and the freedom to put a chosen faith (if any) into practice." ${ }^{21}$ That just about covered the waterfront, with the possible exception of the question of government's symbolic support for religion. ${ }^{22} \mathrm{He}$ noted that accommodation "does not fit comfortably within the current doctrines," identifying "a class of permissible government actions toward religion, which have as their purpose and effect the facilitation of religious liberty. Neither strict neutrality nor separationism

${ }^{16}$ When Kurland wrote, the Supreme Court had considered no cases involving statutory accommodations. The first Supreme Court decision considering in detail the constitutionality of a statutory accommodation appears to be Texas Monthly v. Bullock, 489 U.S. 1 (1989) (holding unconstitutional a statutory provision exempting religious publications from a state sales tax). However, on the subject of statutes exempting conscientious objectors from military conscription, Kurland did observe that: "One might have thought that ... this would have presented the Court with a serious problem of compliance with the first amendment. It did not. Perhaps because the case in which it was presented was not an appropriate case." Kurland, supra note 11 , at 22 . He did not discuss statutory accommodations elsewhere in the article, although perhaps one can glean something from his observation in his conclusion that his "test is meant to provide a starting point for the solution to problems . . . not a mechanical answer to them." Id. at 96.

${ }^{17}$ Compare Braunfeld v. Brown, 366 U.S. 599 (1961) (rejecting a claim that a retail store whose owners closed it for religious reasons on Saturday, should have a constitutional exemption from a Sunday-closing requirement), with Sherbert v. Verner, 374 U.S. 398 (1963) (requiring as a matter of constitutional law that a Saturday-observer who could not find employment compatible with her beliefs be provided with unemployment compensation).

18374 U.S. 398 (1963).

${ }^{19}$ Sherbert was followed by a handful of other unemployment compensation cases, such as Thomas v. Review Board, 450 U.S. 707 (1981) (requiring that a Jehovah's witness be given unemployment compensation after he resigned rather than engage in the production of weapons). The era in which any accommodations were held to be constitutionally required ended with Smith. See Emp't Div. v. Smith, 494 U.S. 872, 890 (1990).

${ }^{20}$ McConnell, Accommodation of Religion, supra note 1, at 6.

${ }^{21} \mathrm{Id}$. at 1 .

${ }^{22}$ I believe that symbolic support might be subsumed under the category "put[ting] a chosen faith . . . into practice," $i d$., if the relevant practice is voting for symbolic support. 
can account for the idea of accommodation or define its limits." ${ }^{23}$ For McConnell, the primary members of this class of actions were statutory accommodations, which were inconsistent with strict neutrality as defined by Kurland and with separationism understood to prohibit legislation that purposefully provided benefits to religion. ${ }^{24}$

McConnell expressly refrained from distinguishing between mandatory accommodations "compelled under the Free Exercise Clause" and imposed by the courts and permissible accommodations created by statutes that did not violate the nonestablishment principle because, "from the perspective of religious liberty, the nature, justification, and limits of accommodation appear essentially the same when accommodations are instituted by elected officials as when they are ordered by judges." ${ }^{25}$ Acknowledging that his approach could not be reconciled with then-prevailing doctrinal formulations, which treated the purpose of advancing religion as a strong reason for finding a statute unconstitutional, he observed that "all protections of religious liberty . . . 'advance' religion in a sense and are intended to do so."26

What, though, were the limits on the accommodation principle? For McConnell, "the essential distinction is between permissible accommodations, which facilitate religious liberty, and unwarranted benefits, which channel and constrain religious choice." ${ }^{27}$ Three more detailed rules "assist in making this distinction." ${ }^{28}$ First, "[a]n accommodation must facilitate the exercise of beliefs and practices independently adopted rather than inducing or coercing beliefs or practices acceptable to the government." ${ }^{29}$ Vocal prayers organized by school teachers, for example, might be barred by this rule, because some school children might not "independently" choose to pray in that manner. Second, "[a]n accommodation must not interfere with the religious liberty of others by forcing them to participate in religious observance." ${ }^{30}$ Mandatory school prayers that do not provide an exemption for nonbelievers and those who reject such prayers on religious grounds would be barred under this rule. ${ }^{31}$ Third, "[a]n accommodation must not favor one form of religious belief over another." 32 A program of public assistance available only to Christian schools, or only to schools affiliated with monotheistic religions, would be barred under this rule, even if it might otherwise

${ }^{23}$ Id. at 3 .

${ }^{24}$ McConnell's catalogue of "[e]xamples of [a]ccommodation" includes both statutory and court-required accommodations. Id. at 24-25.

${ }^{25} \mathrm{Id}$. at 5 . As I argue below, mandatory and permissible accommodations do differ from the perspective of politics and sometimes in ways that weaken McConnell's argument.

${ }^{26} \mathrm{Id}$. at 6.

${ }^{27}$ Id. at $34-35$.

${ }^{28}$ Id. at 35 .

${ }^{29} \mathrm{Id}$.

${ }^{30}$ Id. at 37.

${ }^{31}$ Id.

${ }^{32}$ Id. at 39. 
be understood as a way of accommodating the beliefs of parents who had religious reasons for objecting to what was taught in the public schools supported by their taxes.

McConnell then applied these principles to two recently decided cases. He argued that Wallace v. Jaffree ${ }^{33}$ erroneously failed to treat a statute requiring a moment of silence at the beginning of the school day as a permissible accommodation: "Many persons feel a need to incorporate prayer into all of life's significant activities . . . . Since the practice of vocal prayer was eliminated from the public schools, these individuals have felt a void." ${ }^{34}$ One might add that the absence of vocal prayer might suggest to such students that even silent prayer was impermissible. Further, McConnell argued that the statute placed "no pressure" on anyone to pray, because students could think about anything that came to mind during the moment of silence, and " $[t]$ he cost imposed on other students is minimal - a moment of time during which ordinary classroom activities do not take place." ${ }^{35}$ Finally, he claimed that a moment of silence in which students can pray or meditate is neutral among religions and even between religion and nonreligion, because meditation can be substituted for prayer for secularists and adherents of religions that do not favor individual prayer independent of ministerial leadership. ${ }^{36}$

McConnell offered similar criticisms ${ }^{37}$ of Estate of Thornton v. Caldor, Inc., which held unconstitutional as an establishment of religion a state statute that required employers to free employees of obligations to work on a day that each employee designated as his or her personal Sabbath. ${ }^{38}$ McConnell argued that, though the question of "inducement" was more substantial than in Wallace, in the end, the statute included safeguards against that possibility in its requirement that the designation be sincere. ${ }^{39}$ Nor would complying with the statute adversely affect the religious liberty of others: not the employer, who would have to bear only the increased costs associated with staffing necessary work, nor other employees, who-with respect to work on days other than their own self-designated Sabbath-could be compensated by premium pay. ${ }^{40}$

McConnell's article changed the terms of debate. First, it demonstrated that statutory accommodations were so firmly fixed in history and practice that neither strict separation nor strict neutrality could be the overarching principles accounting for settled practice ${ }^{41}$ For example, McConnell pointed

\footnotetext{
${ }^{33} 472$ U.S. 38 (1985).

${ }^{34}$ McConnell, Accommodation of Religion, supra note 1, at 42.

${ }^{35} \mathrm{Id}$. at $42-43$.

${ }^{36} I d$. at 43 .

${ }^{37} \mathrm{Id}$. at $51-58$.

38472 U.S. 703 (1985).

${ }^{39}$ McConnell, Accommodation of Religion, supra note 1, at 51, 53.

${ }^{40} I d$. at 53-54. Even extra work not at premium pay would be a "purely secular" cost, not a cost to the other employees' religious liberty. Id.

${ }^{41} I d$. at $8-9$.
} 
out that statutory accommodations in connection with military service for those with religious objections to participation in war-the traditional peace churches such as the Quakers-went back to the nation's origins. ${ }^{42}$

McConnell's article also interred the idea that there could be a general constitutional principle that legislation with the purpose or primary effect of advancing religion was unconstitutional. ${ }^{43}$ As noted, statutory accommodations did have as their principal purpose and their primary, indeed probably exclusive, effect the facilitation of specific religious practices. ${ }^{44} \mathrm{~A}$ constitutional principle inconsistent with longstanding practices is in general not an attractive one.

Finally, in the nonestablishment domain illustrated by McConnell's discussion of Wallace, the article opened the way to cogent arguments that practices that critics described as establishments of religion could often be redescribed as accommodations of religion. ${ }^{45}$ Systems of public assistance to primary and secondary schools affiliated with religious institutions, whether in the form of direct grants or in the form of vouchers, are a good example of practices that could be so described: such systems accommodated the burdens on parents who had reasons based in religion to send their children to religiously affiliated schools, but were unable to afford paying taxes to support public schools as well as the tuition charged by the religiously affiliated schools.

\section{Criticisms of Accommodation of Religion}

McConnell's analysis was generally well received, but it was not invulnerable to criticism. ${ }^{46}$ Unsurprisingly, McConnell did not anticipate two major developments, Employment Division v. Smith ${ }^{47}$ and the legislative response to Smith in the federal Religious Freedom Restoration Act ${ }^{48}$ and in several state-level "little RFRAs." ${ }^{49}$ Prior to Smith, the Court had articulated a doctrine holding that the Free Exercise Clause sometimes required that religious believers be granted exemptions from general statutes, because the general statutes-requiring school attendance beyond junior high school, for

${ }^{42} I d$. at 22 (discussing debates in the House of Representatives in 1789 over religious exemptions from a requirement that every male participate in the militia).

${ }^{43}$ See McConnell, Accommodation of Religion, supra note 1, at 44-48 (analyzing problems associated with legislative purpose and mentioning the question of primary effect).

${ }^{44}$ See id. at 6.

${ }^{45}$ See id. at $42-50$.

${ }^{46}$ For my initial expression of skepticism about McConnell's approach, see generally Mark Tushnet, The Emerging Principle of Accommodation of Religion (Dubitante), 76 Geo. L.J. 1691 (1988).

47494 U.S. 872 (1990).

4842 U.S.C. $\S \S 2000 b b-2000 b b-4$ (2012).

${ }^{49}$ See, e.g., ARIZ. Rev. Stat. § 41-1493 (2007). For links to other state RFRAs, see State Religious Freedom Act, The Religious Liberty Archive, http://www.churchstate law.com/statestatutes/religiousfreedom.asp, archived at http://perma.cc/J6GY-28C7. 
example-imposed excessive burdens on the religious practices of some groups..$^{50}$ The doctrine had not been vigorously applied, but there appeared to be general agreement that a doctrine along those lines was appropriate. ${ }^{51}$ Smith presented a standard case in which a religious believer claimed an exemption from a general statute: adherents to religions in which the use of the psychoactive substance peyote was part of a religious ritual sought an exemption from a general state statute making the use of peyote a criminal offense. ${ }^{52}$ Rather than applying the existing doctrine, which called for a balancing of state interests in the prohibition against the impairment of the religious practice, the Court- to the surprise of many scholars and interested observers ${ }^{53}$ - discarded the doctrine and denied the religious adherents the accommodation that they sought. No longer would the Court invoke the Free Exercise Clause as the basis for a mandatory accommodation. ${ }^{54}$

By sharply reducing the scope of the category of mandatory accommodations, ${ }^{55}$ Smith brought the particular problems associated with permissible accommodations to the fore. Congress responded to Smith with the Religious Freedom Restoration Act, ${ }^{56}$ and several states enacted parallel "little RFRAs." 57 These statutes sought to reestablish some version of the general rule that prevailed before Smith in the sense that they asked the courts to consider whether a religious believer should be given an accommodation,

${ }^{50}$ Wisconsin v. Yoder, 406 U.S. 205, 205 (1972).

${ }^{51}$ See McConnell, Free Exercise, supra note 3, at 1109-10.

${ }^{52}$ Emp't Div. v. Smith, 494 U.S. 872, 872 (1990).

${ }^{53}$ See McConnell, Free Exercise, supra note 3, at 1111 (Smith "stimulated a petition for rehearing joined by an unusually broad-based coalition of religious and civil liberties groups from right to left . . . . Free exercise is no longer wanting for controversy.").

${ }^{54}$ See Smith, 494 U.S. at 878-79 ("We have never held that an individual's religious beliefs excuse him from compliance with an otherwise valid law prohibiting conduct that the State is free to regulate. On the contrary, the record of more than a century of our free exercise jurisprudence contradicts that proposition.").

${ }^{55}$ Smith preserved the possibility that accommodations might be constitutionally required in cases involving religious liberty and some other constitutional right (so-called hybrid rights cases), $i d$. at 882 (describing "hybrid situation[s]"), and in cases where an individualized accommodation was denied within a system structured so as to make available individualized exemptions based on nonreligious grounds, $i d$. at 884 (describing situations that "lent [themselves] to individualized governmental assessment of the reasons for the relevant conduct"). Neither exception has been generative. The only case of which I am aware invoking the "individualized assessment" test, for example, is Rader $v$. Johnston, 924 F. Supp. 1540, 1551-52 (D. Neb. 1996), though I may not have a comprehensive grasp of the field, and at least one case reached a settlement after the U.S. Department of Justice filed a brief asserting that the challenged policy arose in an "individualized assessment" setting, see Cara Bailey, Mormon Student Sues After Scholarship is Taken Away, W. VA. REC. (July 23, 2007), http://wvrecord.com/news/198258mormon-student-sues-after-scholarship-is-taken-away, archived at http://perma.cc/RD 6R-H749.

${ }^{56}$ See Frederick Mark Gedicks, One Cheer for Hobby Lobby: Improbable Alternatives, Truly Strict Scrutiny, and Third-Party Employee Burdens, 38 HARV. J.L. \& GENDER 153, 167-68 n.60-61 (2015) (describing the legislative motivations for enacting RFRA).

${ }^{57}$ See supra note 49. 
under specified conditions, to any generally applicable statute..$^{58}$ The scope of these statutes undermined some of McConnell's arguments dealing with statutory accommodations that addressed specific practices, what I call in the next Part of this Article "targeted" accommodations.

We can see some of the difficulties with the interpretation and application of RFRA and parallel state laws by examining McConnell's subprinciples. First, his discussion of the principle against inducing belief sometimes elided careful distinctions between feigned beliefs and beliefs induced by the availability of accommodations. Consider someone who simply does not like to pay taxes because they reduce the resources he has to buy luxury goods: in a regime allowing accommodations for religious belief, such a person might assert falsely that he has religious objections to paying taxes to support a large military establishment. The person is feigning a religious belief. Purely feigned beliefs are adequately dealt with by a requirement that the beliefs be sincerely held, although one can fairly wonder about the capacity of institutional decision makers, such as arbitrators or administrators of public benefits programs, to determine sincerity..$^{59}$

Induced beliefs are different. Suppose the nation adopts a military draft but accommodates some religious believers by allowing them to perform civilian services rather than military ones. Suppose further that this accommodation is available only to those whose religious beliefs lead them to oppose participation in war in any form, rather than those who oppose participation only in unjust wars as identified, for example, in the Catholic "just war" tradition. ${ }^{60}$ Now consider a person whose religious beliefs are relatively unformed. He might have some vague sense that there are religious principles that counsel against participating in military activities, for example. Such a person might be induced by the accommodation to shape his beliefs to the accommodation, saying — sincerely - that he opposes participation in war in any form. But, had the accommodation been available to those who opposed only unjust wars, perhaps the person would have become a "just war" Catholic.

In discussing induced beliefs, McConnell referred to the "risk that others would be induced to adopt or feign the religion." ${ }^{\prime \prime 1}$ But, as the exam-

${ }^{58}$ See, e.g., Ariz. Rev. Stat. § 41-1493.01(B) ("Except as provided in [the next subsection], government shall not substantially burden a person's exercise of religion even if the burden results from a rule of general applicability.").

${ }^{59}$ My strong impression from the decided cases is that judges assume that beliefs asserted before them are sincere and move on to the next steps of the analysis they are required to perform. $C f$. Burwell v. Hobby Lobby Stores, Inc., 134 S. Ct. 2751, 2778 (2014) ("Arrogating the authority to provide a binding national answer to this religious and philosophical question, HHS . . . in effect tell[s] the plaintiffs that their beliefs are flawed. For good reason, we have repeatedly refused to take such a step."). I suspect, though without any empirical basis, that the same is true of other decision makers asked to determine sincerity.

${ }^{60}$ For the criteria of a just war in this tradition, see The Holy See, The Catechism of the Catholic Church 496, § 2309 (Geoffrey Chapman trans., Villiers House 1994).

${ }^{61}$ McConnell, Accommodation of Religion, supra note 1, at 35 (emphasis added). 
ple suggests and as I develop in more detail below, a more substantial problem may be that the availability of an accommodation will subtly induce a believer to reshape his or her beliefs, where the reshaping results in a sincerely held, but new, belief. Put another way, McConnell sought to distinguish between "beliefs and practices independently adopted" and beliefs induced by the availability of accommodations. ${ }^{62}$ That distinction may be more difficult to draw than his presentation of the problem as a unitary one of feigned-or-induced beliefs indicated.

McConnell offered an important additional consideration that, he argued, would guard against "fraud or undue inducement." ${ }_{63}$ These were "internal guarantees" built into statutory accommodations: for example, "[e]xemption from social security for self-employed persons is limited to those whose church maintains an alternative system for retirement support; exemption from the payment of union dues is accompanied, where possible, by the requirement of an equal contribution to charity." ${ }^{64}$ In these cases, legislatures built internal safeguards into the structure of statutory accommodations, and such safeguards may indeed weigh against the possibility of changes in religious belief induced by the availability of accommodations. But, the Religious Freedom Restoration Act changed things. By design, RFRA lacks those internal safeguards, enacting instead a general standard that courts are directed to implement. ${ }^{65}$ Though it is possible that courts could make an accommodation for union dues conditional on an offsetting charitable contribution, doing so would be a quite dramatic exercise of judicial power. ${ }^{66}$

Next, consider McConnell's argument about teacher-led and vocal prayer in schools: "To conduct state-selected or state-composed prayers in public school classrooms may violate the rights of other children not to participate and may channel religious practice into state-prescribed forms." ${ }^{67}$ For example, children might feel social pressure to stay in the classroom during the prayer and even to mouth the prayer's words. Meanwhile, other religious traditions may reject vocal prayer and petitionary prayers seeking God's help in daily life, in contrast to most state-composed prayers, which

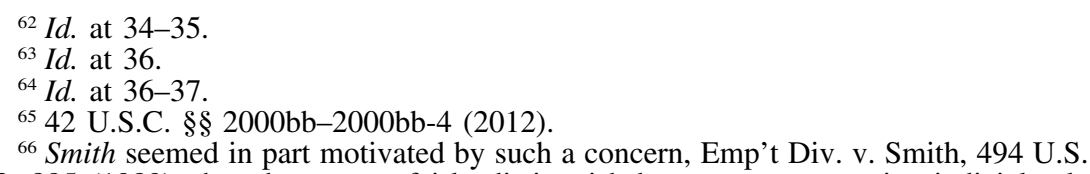
872,885 (1989), though one can fairly distinguish between an expansive judicial role taken on by the courts in implementing the Constitution and a similarly expansive role taken on pursuant to legislative direction.

${ }^{67}$ McConnell, Accommodation of Religion, supra note 1, at 37. McConnell prefaces this with the statement, "[t]his is one reason why vocal public school prayers might not be considered an appropriate accommodation." Id. Acknowledging that McConnell does not expressly contend that teacher-led vocal prayer is not an appropriate accommodation, I nonetheless use the example to illustrate the potential reach of the accommodation rationale. 
are petitionary ${ }^{68}$ Yet, it is rather easy to develop an accommodation-based argument for teacher-led vocal prayer. First, explicitly making participation voluntary, as was true in the Supreme Court's school prayer cases, ${ }^{69}$ may thereby reduce the social pressure to participate to a level that we can expect most objecting students to resist. As Justice Scalia put it in a related context, all that teacher-led vocal prayer requires is that the nonparticipating student sit in respectful silence during the prayer. ${ }^{70}$ Second, just as students may feel a void when they do not pray at school, some students who want to pray may believe-erroneously, to be sure-that they are not allowed to pray in school. Teacher-led vocal prayer overcomes that mistaken belief, accommodating the students' desire to pray. Finally, students are young enough that they may need some guidance in formulating the prayers they want to say, and the teacher can provide that guidance without "channel[ing] religious practice into state-prescribed forms." $"$ F1 For myself, I find this argument for treating teacher-led vocal prayer as an accommodation roughly as persuasive as McConnell's argument with respect to Wallace.

Finally, the principle that accommodations cannot be sect-preferential may be more problematic in practice than McConnell suggested. First, as he acknowledged, statutory accommodations dealing with specific practices "tend to be enacted piecemeal, as part of the laws pertaining to the particular subject matter." 72 And, he continued, "[i]t is not a sign of religious favoritism that a state, in the course of considering one area of the law, should make accommodation to a religious practice directly pertinent to that area without surveying other areas of law for appropriate accommodations to other practices or forms of belief." 73 This formulation of accommodations places a great deal of weight on the characterization of the "particular subject matter." Sometimes characterizing the subject in one way will avoid sect preference, while characterizing the same subject in another way produces sect preference. That was the case in Board of Education of Kiryas Joel School District v. Grumet. ${ }^{74}$ There, the Court held unconstitutional a statute creating a school district for the Village of Kiryas Joel to accommodate village residents' religious objections to sending children who needed special education classes to other districts. ${ }^{75}$ The Court's concern was in part with sect preference: the State created a district for a specific religious de-

${ }^{68}$ For examples of petitionary prayer drawn from the case law, see Lee v. Weisman, 505 U.S. 577, 581-82 (1992) ("God of the Free, . . May our aspirations for our country and for these young people, who are our hope for the future, be richly fulfilled."); Engel v. Vitale, 370 U.S. 421, 422 (1962) ("Almighty God . . . we beg Thy blessings upon us, our parents, our teachers and our Country."). (1963).

${ }^{69}$ Engel, 370 U.S. at 430; Abington Sch. Dist. v. Schempp, 374 U.S. 203, 207

\footnotetext{
${ }^{70}$ See Lee v. Weisman, 505 U.S. 577, 637 (1992) (Scalia, J., dissenting).

${ }^{71}$ McConnell, Accommodation of Religion, supra note 1, at 37.

${ }^{72} \mathrm{Id}$. at 40.

${ }^{73}$ Id.

${ }^{74} 512$ U.S. 687 (1994).

${ }^{75} \mathrm{Id}$. at 692.
} 
nomination, and there was no assurance that it would respond similarly to other religiously based requests for new school districts. ${ }^{76}$ Yet, this is a direct response to a specific problem submitted for legislative decision. Is the subject matter here the sect-preferential "problems of the Village of Kiryas Joel" or the sect-neutral "problems of public education to which some have religious objections"? I doubt that we can answer that question in a way that does not "favor one form of religious belief over another" 77 (or disfavor one to another).

Kiryas Joel illustrates another difficulty with accommodations focused on specific practices. They will be the product of ordinary legislative politics. Legislators will consider the political benefits and costs to be gained by enacting the accommodation-how politically powerful are the proposals' supporters and opponents? It would be miraculous were those political calculations to result in outcomes that were not sect-preferential in the aggregate: put bluntly, congregants of the Reunification Church are much less likely to receive accommodations in subject matter areas of interest to them than were the Satmar Hasidim in Kiryas Joel in their subject matter area of interest. Of course, this is not sect preference within a single subject matter area, but sect preference across subject matter areas is troubling nonetheless.

\section{The Legacy of Accommodation of Religion}

Accommodation of Religion is an enduring classic in the literature on the Religion Clauses. Even after Smith it continues to set the terms of debate, now conducted with respect to the Religious Freedom Restoration Act. This Article's next Part argues that Smith and the Religious Freedom Restoration Act have changed the political context within which debates about accommodation occur, not to the long-term advantage of the principles McConnell articulated.

\section{The Contemporary Political Economy of Statutory Accommodations}

In this Part, I examine the political economy of contemporary statutory accommodations, that is, how basic institutional features affect the likelihood that such accommodations will be adopted and the likelihood of divisive political controversy over them. To anticipate the argument's conclusions: general accommodations dealing with all sorts of business practices that affect a wide range of religious believers will be easier to enact than targeted accommodations dealing with a narrow range of religious beliefs, and accommodations affecting well-established public policies will be

\footnotetext{
${ }^{76} \mathrm{Id}$. at $702-03$.

${ }^{77}$ McConnell, Accommodation of Religion, supra note 1, at 39.
} 
less controversial than those affecting public policies that are a matter of current public controversy.

After Smith the law of religious accommodations is statutory: under RFRA in federal law, under "little RFRAs" on the state level, and in connection with accommodations built into specific statutes, if legislatures choose to insert them. Pre-Smith cases illuminate the politics associated with statutory accommodations. There are two dimensions of interest: (1) whether accommodations are targeted or general, ${ }^{78}$ and (2) who the constituencies of support for the substantive policies that accommodations affect are. These dimensions affect the politics of accommodations. The consensus favoring accommodations dissolved when it became clear that general statutory accommodations might become available to those with religious objections to certain types of interactions with women and LGBT people in circumstances when it would have been impossible to enact accommodations targeted specifically at those objections.

\section{A. Targeted and General Accommodations}

Consider Goldman v. Weinberger, ${ }^{79}$ a pre-Smith decision in which the Supreme Court rejected a mandatory accommodation for discreet headgear to be worn by members of the military under their military headgear. ${ }^{80}$ Goldman was an ordained rabbi serving as a clinical psychologist in a military mental health clinic. ${ }^{81}$ His religion counseled him to wear a yarmulke on his head at all times. ${ }^{82}$ A military regulation allowed members of the services to wear only the headgear prescribed by military regulations, which did not authorize wearing yarmulkes. ${ }^{83}$ The Court held that applying the regulation to Goldman did not violate his constitutional rights because the military interest in having a uniform set of military clothing and headgear outweighed the impairment of Goldman's religious beliefs. ${ }^{84}$ Congress responded with a statutory accommodation. ${ }^{85}$ It required that the military allow service members to wear "neat and conservative" coverings when doing so was required by the members' religious belief. ${ }^{86}$

${ }^{78}$ The distinction is not novel, though the terminology may be. See, e.g., Marci A. Hamilton, Religious Institutions, the No-Harm Doctrine, and the Public Good, 2004 BYU L. Rev. 1099, 1202 (2004) [hereinafter Hamilton, Religious Institutions]; MARCI A. Hamilton, God vs. the Gavel: The Perils of Extreme Religious Liberty 34 (rev. 2nd ed. 2014) (distinguishing between "practice specific" accommodations and "blind" accommodations).

79475 U.S. 503 (1986).

${ }^{80} \mathrm{Id}$. at $509-10$.

${ }^{81} \mathrm{Id}$. at 505 .

${ }^{82} \mathrm{Id}$. at 513 (Brennan, J., dissenting).

${ }^{83} \mathrm{Id}$. at 509.

${ }^{84} \mathrm{Id}$. at $509-10$.

${ }^{85} 10$ U.S.C. $\$ 774$ (2012).

${ }^{86} 10$ U.S.C. $\$ 774(b)(2)$ (2012). 
The statutory accommodation emerged from extended consideration of headgear policy by Congress and the Department of Defense. ${ }^{87}$ Opponents expressed concern that allowing individual members of the military to depart from a universally applied standard governing their uniforms would undermine the cohesiveness of the military and would be difficult to administer in light of the wide range of practices arguably covered by the accommodation. ${ }^{88}$ In light of this opposition, the fact that Congress enacted the statute can fairly be understood as embodying an implicit congressional evaluation of the costs and benefits associated with the accommodation. It could do so because both costs and benefits were reasonably apparent from the statute itself.

The same is true more generally of accommodations targeted at specific religious practices ${ }^{89}$ Targeted accommodations for military headgear and consumption of psychoactive drugs in religious ceremonies are obvious illustrations. Consider first the political benefits of enacting a targeted accommodation. Constituents who themselves gain from the accommodationpeople like Goldman — will support a legislator who votes for it. ${ }^{90}$ They form what public choice theorists call a concentrated group. ${ }^{91}$ They will be supported by those who believe that religious liberty requires, or at least encourages, legislation that does as much as it can to accommodate religious belief. In sum, beneficiaries and a certain kind of civil libertarian will vote for a legislator who supports a targeted accommodation.

Now consider the policy costs of enacting a targeted accommodation. Legislators faced with a proposed targeted accommodation can compile information about the costs of the accommodation, which might include information about how many people were likely to seek to use the

\footnotetext{
${ }^{87}$ For a detailed recounting, see Dwight H. Sullivan, The Congressional Response to Goldman v. Weinberger, 121 MiL. L. REv. 125, 134-37 (1988).

${ }^{88} \mathrm{Id}$. at 144 (quoting Senator Chafee's concern with "the accentuation of the differences between the members of our military forces").

${ }^{89}$ As McConnell put it in a somewhat different context:
}

[T] he government is in a better position than the courts to evaluate the strength of its own interest in governing without religious exceptions. Where the government determines that it can make an exception without unacceptable damage to its policies, there is no reason for a court to second-guess that conclusion . . . .

McConnell, Accommodation of Religion, supra note 1, at 31.

${ }^{90}$ Throughout I also consider as "constituents" people from outside a legislator's district who can provide important political support to the legislator by means such as contributions.

${ }^{91}$ See Glynn S. Lunney, Jr., A Critical Reexamination of the Takings Jurisprudence, 90 Mich. L. Rev. 1892, 1950-52 (1992) (explaining the terminology and the political consequences of a group's concentration). Public choice theory, as I use the term in this Article, offers an account of how public policy is developed by assuming that policy results from aggregating the preferences of individuals who express those preferences in politics by calculating the costs and benefits of such participation, compared to the costs and benefits of alternative uses of their resources. It is, roughly speaking, the application of the analysis of product markets to politics and treats public policy as the relevant product. 
accommodation, about the administrative costs likely to be associated with determining whether an individual claimant satisfies the statutory standard, and about the impairment of the substantive policy goals underlying the existing statute, such as military cohesion or abuse of psychoactive drugs. With that information in hand, legislators can decide whether the benefits to religious liberty of the accommodation outweigh the policy costs associated with the accommodation.

Importantly, legislators must incorporate into their political calculus the voters and interest groups that think that those policy costs are substantial: crudely, does a legislator have more constituents who are interested in religious liberty than constituents who are interested in the underlying substantive policy? For present purposes, consider accommodations that impair the effectiveness of programs where benefits are distributed widely across the population: public education or unemployment compensation. The beneficiaries are, in public choice terms, a diffuse interest group. And, public choice theory suggests that concentrated interest groups-the beneficiaries of targeted accommodations-will ordinarily prevail over diffuse ones-the beneficiaries of the substantive programs. ${ }^{92}$

General accommodations, like the Religious Freedom Restoration Act, are different from targeted ones. There, a diffuse interest group of potential beneficiaries of accommodations faces a diffuse interest group of beneficiaries of substantive policy. The groups are diffuse because, at the time of enactment, no one can know whether he or she will be on one or the other side of an accommodation-policy trade off. Where diffuse interest groups face off against each other, public choice theory has little to say.

The reason that the groups on both sides are diffuse is that assessing the costs and benefits of enacting such an accommodation is, for all practical purposes, impossible at the time of enactment ${ }^{93}$ Even with respect to already enacted statutes, constituents and legislators can have no real idea about which ones will be subjected to claims for accommodation, what those claims will be, and how substantially accommodating the claims will impair the statutes' underlying policies. Nor, obviously, can they have that information about statutes that will be enacted in the future. General accommodation statutes are delegations to the future-to future legislatures in the first in-

${ }^{92}$ See id. at 1951-52 ("When a concentrated group and a dispersed group compete in the legislature, these differences in organizational costs will make the voice of the concentrated group stronger in comparison to the voice of the dispersed group than it would have been had the two groups been of the same size and homogeneity.").

${ }^{93}$ I note as well that a concern Justice Scalia expressed about the Voting Rights Act at the oral argument in Shelby County v. Holder, 133 S. Ct. 2612 (2013), is applicable to the Religious Freedom Restoration Act. Justice Scalia worried that the very name of the Voting Rights Act would induce support: "Even the name of it is wonderful: The Voting Rights Act. Who is going to vote against that in the future?" Transcript of Oral Argument at 48, Shelby Cnty. v. Holder, 133 S. Ct. 2612 (2013) (No. 12-96). The same concerns apply to the Religious Freedom Restoration Act: Who is going to vote against restoring religious freedom? 
stance, then to executive officials charged with implementing substantive statutes in ways compatible with the general accommodation statute, and finally to the courts.

Delegations of that sort are of course quite common in substantive legislation. Legislators decide that, for reasons implicating both their political interests and their expertise, authorizing other officials to spell out the details of statutory policy is the sensible course. Environmental legislation provides a useful example. Congress sets the broad parameters of policy. That policy is a complex blend of concern for the environment, concern for the national economy, and concern for federalism (and more). Having set those parameters in statutory language, Congress charges the Environmental Protection Agency, with supervision from the courts and future Congresses, to work out how best to implement the policy. ${ }^{94}$

General accommodations of religion are substantially different as delegations. Legislators know one policy matter of interest-their concern for religious freedom. But, they cannot know the other policies that will go into the blend with respect to statutes to be enacted in the future. And, though in theory they might be said to know what substantive policies are embodied in already enacted statutes, in practice they cannot effectively canvass the statute books to assess how accommodations would affect the implementation of those policies. This is particularly so in light of the fact that they cannot in practice know what kinds of religious objections might be made in a religiously pluralist society to any specific statute. Nor can legislators know much about the institutional characteristics of the agencies, including the courts, to which they are delegating authority. For environmental statutes, the enforcing agencies are few in number, and much is in the hands of a single agency, the Environmental Protection Agency. In contrast, for general accommodations, the enforcing agencies are, in practice, every government agency, ranging from land-use planning councils to school boards to prison administrators, with widely varying institutional characteristics and capacities.

The cost-benefit analysis of general accommodations is thus substantially different from that of targeted accommodations. Legislators can make judgments about the benefits side but are not in a good position to evaluate the cost side. Of course, there is a continuum between tightly targeted accommodations-for example, the Goldman statute ${ }^{95}$ — and entirely general ones such as the Religious Freedom Restoration Act. Should we characterize the Religious Land Use and Institutionalized Persons Act ${ }^{96}$ as targeted because it focuses only on land use and institutionalized persons, or as general

${ }^{94}$ EPA v. EME Homer City Generation, L.P., 134 S. Ct. 1584 (2014), provides a good recent example of a statute, the Clean Air Act, that delegates a great deal of interpretive authority to the Environmental Protection Agency.

9510 U.S.C. § 774 (2012); Goldman v. Weinberger, 475 U.S. 503 (1986).

96114 Stat. 803 (2000), codified at 42 U.S.C. $\$ \$ 2000 \mathrm{cc}$ to $2000 \mathrm{cc}-5$. 
because there are so many land uses and institutionalized persons affected by it that calculating its costs is impossible? ${ }^{97}$

Put perhaps a bit too strongly: legislators can support general accommodations because doing so is politically cheap. There is a group of unknown size that will applaud the statute's enactment, and no one is in a good position to express concern about the costs the statute will impose in the future. Religious believers will like the statute, no matter what their beliefs are, because they can imagine themselves seeking an accommodation with respect to some as-yet-unenacted statute, and civil libertarians will like it because, as McConnell observed, it advances religious liberty. ${ }^{98}$ These are the concentrated interest groups of public choice theory. Who will oppose the statute? In some sense, everyone, because anyone might imagine a statute advancing a substantive policy she or he cares deeply about. But, in public choice terms, a position that everyone opposes in principle is one that no one will oppose in practice because of the problem of "free riders." It is not worth devoting one's personal resources to guarding against imaginable but not yet real possibilities, because-as a result of the fact that everyone has an interest in guarding against the possibilities-one expects that someone else will do so and hopes to free ride on those expected efforts.

\section{B. Substantive Policies and Their Supporters}

A second dimension of interest concerns the substantive policies affected by accommodations. Here my approach is basically inductive: What substantive policies have been implicated in accommodation cases?

\section{Accommodations for Traditional Police Power Regulations and Progressive-era and New Deal Legislation}

During the era of mandatory accommodations, the Supreme Court considered cases involving unemployment benefits, ${ }^{99}$ military headgear, ${ }^{100}$ social security taxes, ${ }^{101}$ high school education, ${ }^{102}$ social security numbers, ${ }^{103}$ government-sponsored development in national parks, ${ }^{104}$ and the use of

${ }^{97}$ Hamilton, Religious Institutions, supra note 78 , at $115-50$, is perhaps the most forceful supporter of the argument that the Religious Land Use and Institutionalized Persons Act should be treated as a general accommodation for the reasons outlined in the text.

${ }^{98}$ See McConnell, Accommodation of Religion, supra note 1, at 19-20.

${ }^{99}$ Sherbert v. Verner, 374 U.S. 398 (1963).

${ }^{100}$ Goldman v. Weinberger, 475 U.S. 503 (1986).

${ }^{101}$ United States v. Lee, 455 U.S. 252 (1982).

102 Wisconsin v. Yoder, 406 U.S. 205 (1972).

${ }^{103}$ Bowen v. Roy, 476 U.S. 693 (1986).

${ }^{104}$ Lyng v. Nw. Indian Cemetery Protective Ass'n, 485 U.S. 439 (1988). 
psychoactive drugs. ${ }^{105}$ I call these traditional police power and Progressive and New Deal programs.

On the few occasions that the Court found an accommodation to be constitutionally required, little controversy arose, whereas the Court's denial of accommodations was somewhat more controversial, at least among interested elites. ${ }^{106}$ One reason that the regime of mandatory accommodations generated little political controversy may be that the substantive programs the cases implicated, such as public education, were strongly entrenched politically. Had accommodations seriously impaired the underlying substantive policies, those policies had political constituencies that would have mobilized to defend the programs. Or, put another way, the constituencies supporting the underlying policies concluded that not much was at stake when accommodations were granted. Whether an Amish employer paid social security taxes for his employees or not, the social security system was going to continue largely unaffected, and so too with accommodations in public education and the unemployment compensation system.

\section{Contemporary Accommodations for the Modern Equality Agenda}

Accommodations have become politically controversial in one specific setting: claims for accommodations with respect to legislation we can associate with the Great Society's agenda of expanding the domain of social equality broadly understood. The Supreme Court has considered the question of accommodations three times since Smith. ${ }^{107}$ Two of those instances were traditional police power cases, involving psychoactive drugs and policies dealing with prisoners. ${ }^{108}$ And, consistent with the earlier pattern, those cases occasioned almost no political controversy.

The third case, Burwell v. Hobby Lobby, ${ }^{109}$ is quite different. The decision generated a large critical (and supportive) commentary, which is to say that it became the focus of real political controversy. That would have been true whatever the Court did in Hobby Lobby, as we can see from the controversy over religious accommodations in connection with gay rights, marriage equality, and some aspects of gender equality that occurred before Hobby Lobby. ${ }^{110}$ And, it may be important to observe, sometimes the contro-

${ }^{105}$ Emp't Div. v. Smith, 494 U.S. 872 (1990).

${ }^{106}$ See, e.g., Mark S. Rains, Note, United States v. Lee: An Insensitive Approach to the Free Exercise of Religion, 18 Tulsa L. Rev. 305, 334-35 (1982).

${ }^{107}$ I exclude City of Boerne v. Flores, 521 U.S. 507 (1997), from this list because the Court did not address the merits of the claim for exemption.

${ }^{108}$ Gonzales v. O Centro Espirita Beneficiente Uniao Do Vegetal, 546 U.S. 418, 418 (2005) (psychoactive drugs); Cutter v. Wilkinson, 544 U.S. 709, 709 (2005) (policies dealing with prisoners).

109134 S. Ct. 2751 (2014).

110 See, e.g., Elane Photography v. Willock, 309 P.3d 53, 53 (N.M. 2013), cert. denied, 134 S. Ct. 1787 (2014) (holding that a wedding photographer who declined to photograph a celebration of a same-sex wedding performed elsewhere violated the state's public accommodations law); Court Rules Bakery Illegally Discriminated Against Gay 
versies arose in connection with proposals for what proponents contended were targeted accommodations, such as proposals for accommodations in connection with marriage equality. ${ }^{111}$

The reason for the controversy is that these issues are associated with an underlying agenda of expanding equality that itself is politically controversial. Public policies with respect to abortion and contraception, which some understand as components of an agenda of increasing substantive equality between women and men; public policies with respect to providing public services and statuses, such as marriage, and private services, such as hotel rooms and wedding cakes to LGBT people: these are important issues in the ongoing "culture wars."

In light of these issues, one sentence in Hobby Lobby is especially interesting: "The Government has a compelling interest in providing an equal opportunity to participate in the workforce without regard to race, and prohibitions on racial discrimination are precisely tailored to achieve that critical goal." 112 The sentence says that the courts would not interpret the Religious Freedom Restoration Act to authorize accommodations for religious beliefs about racial inequality, but-ominously from the perspective of those interested in the modern equality agenda-says nothing about other aspects of that agenda, such as equality in connection with gender and sexual orientation. At least in the Court's formulation, the elimination of racial discrimination is a compelling state interest, sufficient to prevail over the general principles of accommodation of religion, whereas the elimination of discrimination against other "modern" protected classes might not be similarly sufficient.

\section{Summary on the Political Economy of Accommodations}

Although, as I have emphasized, the preceding discussion deals with dimensions and so with points on a continuum rather than sharply defined categories, it might be useful to generate a two-by-two chart summarizing the argument.

Couple, ACLU OF COLORADO, http://aclu-co.org/court-rules-bakery-illegally-discrimina ted-against-gay-couple/, archived at http://perma.cc/H7QC-TSWZ (describing a case involving a baker who refused to provide a cake for a wedding reception for a gay couple).

${ }^{111}$ Compare Executive Summary of Statement of William Bassett, Thomas Berg, Robert Destro, Carl Esbeck, Marie Failinger, Edward Gaffney, Richard Garnett, Michael McConnell, and Robin Wilson on Religious Liberty Implications of Proposed Hawaii Marriage Equality Act of 2013 (Oct. 28, 2013), archived at http://perma.cc/Z9KG-8UTG, with Dale Carpenter et al., Re: Religious Liberty and Marriage for Same-Sex Couples, Chicago Tribune, Oct. 23, 2013, archived at http://perma.cc/77ER-F5U5.

${ }^{112}$ Burwell v. Hobby Lobby Stores, Inc., 134 S. Ct. 2751, 2783 (2014). 


\begin{tabular}{|c|c|c|}
\hline & Targeted & General \\
\hline Police power & $\begin{array}{l}\text { 1. Costs/benefits easily } \\
\text { assessed } \\
\text { 2. Concentrated interest group } \\
\text { against diffuse one } \\
\text { 3. Possibly controversial but } \\
\text { likely to be enacted }\end{array}$ & $\begin{array}{l}\text { 1. Costs/benefits difficult to } \\
\text { assess at enactment, easily } \\
\text { assessed in application } \\
\text { 2. Diffuse interest groups on } \\
\text { both sides at enactment } \\
\text { 3. Likely uncontroversial, no } \\
\text { "prediction" about enactment }\end{array}$ \\
\hline Equality agenda & $\begin{array}{l}\text { 1. Costs/benefits easily } \\
\text { assessed } \\
\text { 2. Concentrated interest groups } \\
\text { on both sides } \\
\text { 3. Almost certainly } \\
\text { controversial, no "prediction" } \\
\text { about enactment }\end{array}$ & $\begin{array}{l}\text { 1. Costs/benefits difficult to } \\
\text { assess at enactment, easily } \\
\text { assessed in application } \\
\text { 2. Today, concentrated interest } \\
\text { groups on both sides } \\
\text { 3. Probably controversial, no } \\
\text { "prediction" about enactment }\end{array}$ \\
\hline
\end{tabular}

This table suggests that the distinction between targeted and general accommodations may matter when legislators consider whether to enact such accommodations, but that it falls by the wayside after enactment. At that point-when general accommodation statutes are applied to specific claims - the distinctions among underlying substantive policies are dispositive. This situation suggests, though, that the prospect for enacting general accommodations (or accommodations near the "general" end of the continuum) is not favorable for the near future, because now proponents of the equality agenda know that such statutes may be applied to limit the reach of that agenda. So, for example, the analysis suggests that it will be quite difficult to enact statutes targeted at accommodating those who have the religious belief that married women with children should devote their time to childcare at home rather than work in the market economy, and so wish to refuse to hire such women for ordinary jobs. Similarly difficult would be enacting statutes aimed at accommodating those who have religious beliefs that counsel against facilitating marriages between same-sex individuals by providing ordinary commercial services such as ballrooms and food.

An additional point is that recent attention to the political economy of general accommodations should probably turn to the recipients of the delegations under such statutes: executive agencies and the courts. For example, what are the conditions under which executive agencies will be more responsive than the courts to those seeking accommodations? Will the answer to that question differ depending on which executive agency receives the delegation? For example, will a programmatic agency, such as the military, with a statutory charge to accommodate those with religious objections to its general programs be more responsive than the courts to purely military concerns 
(or will the military do what it is supposed to do, which is to take orders from civilians and accommodate generously)? What about an agency with a broad rights-protecting agenda, such as the Civil Rights Division of the Department of Justice? How will it deal with the conflicting pulls of religious liberty and women's and LGBT rights? For now, all I can say is that I have been unable to make progress in my own thinking about that issue.

Substantial political controversy has emerged both in connection with general accommodations and with some more targeted ones. This controversy arises in part because, as discussed in Part I, the Court and most commentators have rejected the strict separationist position. Part III next uses the fact of such controversy in a non-standard defense of a regime of strict separation that leaves no room for accommodations, mandatory or permissible (that is, court-required or legislatively enacted).

\section{Pro-Religion Strict Separation}

Contemporary defenses of a regime of strict separation come almost entirely from secularists. This was not always so. Historically, Baptists were strong proponents of a version of strict separation, ${ }^{113}$ and much of the organized Jewish community was as well. ${ }^{114}$ But, during those historical periods, "strict separation" was counterposed to a regime in which the government provided support to dominant religious denominations, sometimes as part of a system of supporting religion in general. ${ }^{115}$ In that version, the idea of strict separation can be worked into many of today's ideas about the nonestablishment principle such as noncoercion and nonendorsement.

It is clearly more difficult to work the issue of accommodations into those ideas. Accommodations were not prominent in earlier discourses about strict separation, and to the extent they came up, traditional Baptists were mostly indifferent but vaguely supportive of accommodations; Jews were more generally supportive. ${ }^{116}$ But, the idea of accommodations fits awkwardly with common strict separation ideas such as coercion, nonendorsement, and impermissible purpose and effect. Take coercion: accommodations are defensible as ways to ensure that people are not coerced, overtly or subtly, out of their religious beliefs. And nonendorsement: in a straightforward sense, accommodations endorse the faith commitments of those who receive them. And finally, purpose and effect: as McConnell

${ }^{113}$ For an account written from a Baptist perspective, see WiLliam M. PINSON, JR., Baptists and Religious Liberty: A Baptist Doctrine and Heritage Study for Life TODAY (2007).

${ }^{114}$ For an account of religious liberty from a long-time lawyer for the American Jewish Congress, see Leo Pfeffer, Church, State, and Freedom 604-05 (1953).

${ }_{115}$ Justice Black's account of the historical background to the Establishment Clause in Everson v. Board of Education, 330 U.S. 1, 8-12 (1947), juxtaposes strict separation to regimes of government support of dominant denominations.

${ }^{116}$ See Leo Pfeffer, Religion, State, and the Burger Court xi-xii (1984). 
showed, in an equally straightforward sense accommodations have the purpose and effect of advancing, or at least of not inhibiting, faith commitments. ${ }^{117}$

Here, I sketch an argument for a pro-religion regime of strict separation that rejects accommodations. ${ }^{118} \mathrm{I}$ emphasize that the argument is not that the Constitution properly interpreted creates a regime of strict separation. But, with respect to accommodations, the argument for strict separation is compatible with the Religion Clauses as currently interpreted. The argument can be put as one identifying a series of pro-religion policy considerations that should influence legislators when they consider whether to enact either a targeted or a general accommodation-and that influence should lead them to refrain from enacting any accommodations. Under Smith, doing so is entirely consistent with the Constitution: accommodations are never mandatory, always discretionary. ${ }^{119}$ My pro-religion strict separation argument is that that discretion should be exercised against enacting accommodations. ${ }^{120}$

\section{A. The Components of Pro-Religion Strict Separation}

The pro-religion strict separation argument picks up some pieces from more traditional religious and legal arguments for strict separation, but supplements them with thoughts drawn from other religious sources. The primary components are: (1) a traditional concern that interactions between religion and government run a real risk of corrupting religion, turning it away from its role in the service of a deity or deities and towards a role in the public sphere, and (2) an equally traditional acknowledgement that religion and government operate in separate spheres. However, the pro-religion strict separation argument pushes these traditional ideas well beyond their

${ }^{117}$ McConnell, Accommodation of Religion, supra note 1, at 3.

${ }^{118}$ For my earlier effort to develop an argument for pro-religion strict separation, see Mark Tushnet, Questioning the Value of Accommodating Religion, in LAW AND ReLIGION: CRitical Essays 245 (Stephen M. Feldman ed., 2000).

119494 U.S. 872, 888-90 (1990).

${ }^{120}$ With respect to other aspects of government-religion interaction, pro-religion strict separation is consistent with some well-considered views, but incompatible with others. Using Kurland's framework, we can say that facially neutral laws that have no disproportionate effect favoring religion are constitutionally permissible. Everson $v$. Board of Education, 330 U.S. 1, 17-18 (1947), so holds. (For myself, I believe that the increasing privatization of public services-buses for school children in Everson, police and fire services in standard examples in discussions of strict neutrality-has made it more plausible to contend that strict separation requires the exclusion of religious institutions from the benefits of even such programs: just as religious institutions have to pay to acquire the real property on which their buildings are located, so too might they have to pay to acquire police and fire services.) Pro-religion strict separation would treat facially neutral laws that have a disproportionate effect favoring religion as problematic, contrary to current law. But cf. Mueller v. Allen, 463 U.S. 388, 391 (1983) (upholding a facially neutral statute providing tax assistance to parents for school-related expenditures, the vast bulk of which went to parents who sent their children to religiously affiliated schools). 
origins. In addition, the argument includes some supplementary components sounding in policy, to the effect that religion is better off when it is not accommodated.

\section{Corruption of Religion}

Andrew Koppelman has provided a comprehensive examination of long-standing arguments that formal interactions between government and religion have a tendency to corrupt religion. ${ }^{121}$ The focus of concern has been traditional establishments of religion, in which government provides material support to religious institution. So, for example, James Madison's Memorial and Remonstrance against Religious Assessments, written to oppose a proposal to impose a tax for support of religious institutions in Virginia, states, "During almost fifteen centuries, has the legal establishment of Christianity been on trial. What have been its fruits? More or less in all places, pride and indolence in the Clergy, ignorance and servility in the laity . . . ." 122 Similarly, Thomas Jefferson in his Act for Establishing Religious Freedom wrote that religious tests for office "tend[ ] . . . to corrupt the principles of that very religion it is meant to encourage, by bribing, with a monopoly of worldly honours and emoluments, those who will externally profess and conform to it . . .".123

These versions of the concern that legal establishments of religion and similar policies corrupt religion are not directly applicable to accommodations, which are available to people whose already existing beliefs are burdened by general regulations. But accommodations can induce a more subtle form of corruption, in which people subtly and perhaps unknowingly change their beliefs because they know that accommodations are available for some beliefs and not others.

To return to an example introduced earlier, consider an exemption from military service for those conscientiously opposed to war but only to war in all its forms. The availability of the exemption may lead people to change their religious views, abandoning their previously held beliefs about a just war tradition in favor of a more comprehensive pacifism. Of course, people rethink their faith commitments regularly, and perhaps we should not characterize this sort of accommodation-induced change in belief as "corruption." But, the effect extends beyond the individual: the religion committed to the just war tradition may be weakened when some of its members are induced by the availability of an accommodation to change their beliefs.

${ }^{121}$ Andrew Koppelman, Corruption of Religion and the Establishment Clause, 50 WM. \& MARY L. ReV. 1831 (2009).

${ }^{122}$ James Madison, Memorial and Remonstrance against Religious Assessments, in 8 PAPERS 298, para. 7 (June 20, 1785), archived at http://perma.cc/CBB6-GH6B (emphasis added).

${ }^{123}$ Thomas Jefferson, The Virginia Act for Establishing Religious Freedom (Jan. 16, 1786), archived at http://perma.cc/88LQ-7GA2. 
Yet, why should that sort of change be described as "corruption"? Faith traditions themselves change as they interact with society: consider developments internal to the Church of Jesus Christ of the Latter Day Saints with respect to polygamy and race or developments internal to numerous Protestant denominations with respect to the ordination of women or marriage equality. ${ }^{124}$ These are widely accepted as changes, not corruptions, of the faith traditions, ${ }^{125}$ and indeed it would be deeply inconsistent with ideas of religious liberty to shape public policy with an eye to preventing faith traditions from changing as they confront social change. ${ }^{126}$ But, I think, they are different from accommodation-induced changes because they arise from confrontations between the religious traditions and society, confrontations that then become the occasion for internal discussion and struggle within the traditions. ${ }^{127}$ Schisms sometimes result. Accommodation-induced changes do not, I think, have this confrontational aspect. And, one might think that schisms caused by government policy are a particularly bad thing.

Still, there is another difficulty with characterizing accommodation-induced changes as corruption. Adherents to a tradition may find that the prospective availability of an accommodation conditioned on specific beliefs

${ }^{124}$ For a discussion of these changes in the Episcopal Church, see generally NANCY Carol James, The Developing Schism Within the Episcopal Church, 1960-2010 (2010).

${ }^{125}$ External observers sometimes take the cynical view that these changes are insincere capitulations to external pressure. (This is, I think, the general view held by nonMormons of the Mormon abandonment of the practice of polygamy - and, of course, it is the view of some fundamentalists who associate themselves with the Mormon tradition as well. See Danel W. Bachman \& Ronald K. Esplin, Plural Marriage, in ENCYClOPEDIA OF Mormonism 1091, 1091-95 (Daniel Ludlow ed., 1992) ("Those who [practice polygamy], primarily members of fundamentalist groups, do so outside the Church.").) But, from within the tradition, the changes are entirely sincere. For example, the Mormon tradition incorporates the position that church leaders experience revelations, and for Mormons one such revelation occurred in 1890 to church president Wilford Woodruff with respect to polygamy. Id. at 1095 ("Following a vision showing him that continuing plural marriage endangered the temples and the mission of the Church . . . Woodruff issued the Manifesto in October 1890, announcing an official end to new plural marriages ....").

${ }^{126}$ One can understand some of the "church property" cases as resting on that proposition. For example, Presbyterian Church v. Mary Elizabeth Blue Hull Church, 393 U.S. 440 (1969), was a property dispute occasioned by the secession of the respondent church from the petitioner church. The seceding church contended that the Presbyterian Church, by ordaining women and taking positions on the Vietnam War, had departed from the church's principles where property had been deeded to the church on condition that it adhere to those principles. Id. at $442 \mathrm{n} .1$. The Court unanimously held that the Constitution barred civil courts from determining whether a church had "departed" from its traditional doctrines. $I d$. at $449-50$.

${ }^{127}$ I note that, while this sort of internal struggle may be more obvious in nonhierarchical denominations, it also occurs in hierarchical ones, where the highest authority inevitably considers whether what lower-level congregants and ministers are saying is theologically appropriate. In the Roman Catholic tradition, for example, this occurs through the deliberations within and the actions of the Magisterium. For an overview of the Magisterium and its role in the Church, see generally Richard Gaillardetz, When the Magisterium Intervenes: The Magisterium and Theologians in Today's Church (2012). 
leads them to think more deeply about their commitments. They may use the availability of the accommodation as an occasion to clarify what they truly believe. For example, when an accommodation is available only to those who oppose all wars, someone who unthinkingly accepted the proposition that authoritative religious sources supported only opposition to unjust wars might return to the sources and conclude that they actually support a broader pacifism. Note, though, that once again the example works at the level of individual belief. ${ }^{128}$ There remains the risk that individual struggles over what religious belief requires will weaken existing denominations, which is a version of the traditional nonestablishment concern for corruption of religion.

A related concern about accommodations is that they lower the cost of faith. Many faith traditions take the position that adherence to the specific set of beliefs associated with each should be difficult, a matter of daily struggle. So, for example, many adherents contend that being a Catholic or a Jew should be hard: the religions' demands are substantial ones. One form of corruption might be making belief cheaper. And, perhaps, as some sociologists of religion suggest, demanding religions are more robust than less demanding ones. ${ }^{129}$ As a recent summary puts it, "[t]he watering down of theological and ideological commitments then alienates the existing support base, eroding their loyalty, and eventually undermining the organization's coherence and members." 130

If this is true, accommodations might, once again, weaken those religions. Consider, for example, quietist religions such as the Mennonite, where adherents are to set themselves apart from the world. ${ }^{131}$ Accommodations might preserve one form of separateness, for example by keeping them out of the military or institutions of higher education, but draw government and the religion closer with respect to seeking and administering the accommodation.

In sum, the availability of accommodations can convert internal struggles over what a religion's commitments truly are into requests that the government stabilize the religion's existing commitments. That, I think, can

${ }^{128}$ See, e.g., Thomas v. Review Bd., 450 U.S. 707, 715 (1981) (requiring-during the era of mandatory accommodations-the accommodation of an individual's beliefs about cooperation with war, even though it was not clear that the precise content of the claimant's views was identical to the views of the denomination of which he was a member).

${ }^{129}$ See, e.g., Laurence Iannocone, Why Strict Churches Are Strong, 99 Aм. J. Soc. 1180 (1998).

${ }^{130}$ Anna Grzymala-Busse, Good Clubs and Community Support: Explaining the Growth of Strict Religions, 56 J. Cнurch \& ST. 269, 269-70 (2014).

${ }^{131}$ See Art. 17: Discipleship and the Christian Life, Mennonite Confession of FAITH, http://www.mennolink.org/doc/cof/art.17.html, archived at http://perma.cc/4MT4BKB6 ("Our faithfulness to Christ is lived out in the loving life and witness of the church community, which is to be a separated people, holy to God." (emphasis added)). See also Art. 23: The Church's Relation to Government and Society, MennOnite ConfesSION OF FAITH, http://www.mennolink.org/doc/cof/art.23.html, archived at http://perma .cc/LHF9-3K2D (on the subordinate position of government as compared to God). 
fairly be described as a form of corruption to be considered in evaluating the pro-religion strict separation theory.

\section{The Two Sovereigns}

Recent religion clause scholarship has revived attention to the Calvinist theory of dual sovereignty. ${ }^{132}$ Under that theory the world is divided into a secular domain and a religious or spiritual one, with the government sovereign over the former and God over the latter. ${ }^{133}$ Accommodations might seem compatible with dual sovereignty, because they seem to give sovereignty - the authority to decide whether to accede to government's demands-to religious conscience. Yet, on closer examination, they are not: religious accommodations are exercises of temporal sovereignty. This is evident in the post-Smith regime of permissible accommodations, where legislatures exercise their temporal authority in deciding whether to grant an accommodation, but it is equally true with respect to mandatory accommodations, where the courts-arms of the temporal authority-acting in the name of the Constitution, another temporal authority, determine when accommodations are required. As Smith showed, what a temporal authority chooses to confer-for example, acknowledging the spiritual domain's sovereignty within its sphere-the temporal authority can take away.

In a more theological vein, there are traditions in which God is sovereign over all. ${ }^{134}$ And, "all" really means "all"-Caesar's temporal domain as well as the religious domain. On this view the government simply has no authority over conscience, even to accommodate it. ${ }^{135}$ One might wonder, though, what this means in practice. Should someone who holds that God is

${ }^{132}$ For a recent summary, see Steven D. Smith, The Rise and Decline of AmeriCAN Religious Freedom 20-22 (2014). Hosanna-Tabor Evangelical Lutheran Church v. EEOC, 132 S. Ct. 694 (2012), provoked a spate of writing about its implications for "freedom of the church." See generally Symposium, Freedom of the Church in the Modern Era, 21 J. Contemp. Legal Issues 1 (2013). The contributions to that Symposium make it clear that the "two sovereigns" theory has implications for accommodations generally, and is not confined to accommodations affecting only churches understood as institutions.

133 The urtext is Matthew 22:21 (King James) ("Render therefore unto Caesar the things which be Caesar's, and unto God the things which be God's.").

${ }_{134}$ See Mennonite Confession of Faith, supra note 131 ("We understand that Christ, by his death and resurrection, has won victory over the powers, including all governments. Because we confess that Jesus Christ has been exalted as Lord of lords, we recognize no other authority's claims as ultimate.").

${ }^{135}$ One echo of this position can be heard in Madison's Memorial and Remonstrance, supra note 122:

It is the duty of every man to render to the Creator such homage and such only as he believes to be acceptable to him. This duty is precedent, both in order of time and in degree of obligation, to the claims of Civil Society. Before any man can be considered as a member of Civil Society, he must be considered as a subject of the Governour of the Universe: And if a member of Civil Society, do it with a saving of his allegiance to the Universal Sovereign . . . . 
sovereign over all reject a proffered accommodation when the government asserts its authority over conscience by offering it?

The answer, I think, is not obviously "no." That is, perhaps those who hold this view should not accept an accommodation, which is not quite the same as rejecting it. Consider the military draft. The religious objector who believes in God as the sovereign over all could simply not apply for conscientious objector status, and let the government do what it thinks it has to do (draft or imprison him, but perhaps let him go in silence). Or consider the ongoing controversy over accommodations for religious conscience in connection with the provision for contraceptives as part of coverage under the Affordable Care Act. ${ }^{136}$ Some institutions have taken the position that submitting the form the government requires for them to claim the exemption, a form that on its obverse notes that it will be used to authorize insurance carriers to cover contraceptives, is a form of cooperation with evil that their consciences preclude. ${ }^{137}$ At the time of writing the legal position is this: these institutions need not submit the precise form, as long as they inform the government in some way or another of their objections. ${ }^{138}$ I assume that the next stage in the litigation is that some of these institutions will contend that even so informing the government amounts to cooperation with evil. They will simply stand by, doing nothing at all, when the government asks them about the content of their insurance policies. And, I assume, at some point the courts (an arm of the government) will say that some mechanism for informing the government of one's religious objections is the least restrictive means of administering a scheme of accommodation. ${ }^{139}$ At that point the institutions will face some form of sanction, because-to the government's eye-they are indistinguishable from institutions that have no religious objections.

${ }^{136}$ For a recent intervention, in the form of comments on proposed regulations to implement Hobby Lobby, see Lyman Johnson et al., Comments on the HHS' Flawed PostHobby Lobby Rules (UCLA Sch. of Law Research Paper No. 14-18, 2014), http://papers .ssrn.com/sol3/papers.cfm?abstract_id $=2512860$, archived at http://perma.cc/J47G-QN $8 \mathrm{~S}$.

${ }^{137}$ Wheaton Coll. v. Burwell, 134 S. Ct. 2806, 2812 (2014).

${ }^{138}$ See id. at 2807 (enjoining enforcement of the contraceptive requirement "[i]f the applicant informs the Secretary of Health and Human Services in writing that it is a nonprofit organization that holds itself out as religious and has religious objections to providing coverage for contraceptive services").

${ }_{139}$ One passage in Burwell v. Hobby Lobby Stores, Inc., 134 S. Ct. 2751, 2780-81 (2014), suggests that a less restrictive method of providing contraceptive services without burdening religious conscience is direct funding of those services by the government for employees whose employers have religion-based objections. But, add in objectors who believe that informing the government of their objections-where the effect of doing so is the provision of those services - is cooperation with evil, and the implication is that the government can accommodate them only by direct funding of these services for everyone. And, in a religiously pluralist nation, where someone is going to have a religionbased objection to almost every form of medical service (think here only of Christian Scientists, see Shawn Francis Peters, When Prayer Fails: Faith Healing, ChilDREN, AND THE LAW 109-30 (2008)), the implication is that a regime of accommodations requires direct funding by the government of all medical services. 
One defender of accommodations describes them in these terms: "Religious people are subject to two sets of sometimes competing obligations; a secular government that is decently modest about its own pretensions will try to accommodate those allegiances if it can." ${ }^{140}$ A statement I once heard at a conference on religious liberty from the Mennonite theologian John Howard Yoder suggests a response. As I recall the statement, Yoder said, "It's not the Christian's role to tell Satan how to do his job," the referent of "Satan" being "the government." Yoder was not then focusing on accommodations, and I do not know what he thought about them. But, his statement suggests that seeking an exemption through legislative efforts or through litigation might be inappropriate for a Christian of Yoder's sort: that would amount to a Christian advising Satan how to do his job. And, a Christian of that sort might be suspicious when Satan appears to be "decently modest about its own pretensions." When Massachusetts's legislators established a system of public education in 1647, they began with a reference to "that old deluder, Satan." ${ }^{141}$ Satan is no less a deluder when he offers religious accommodations.

In this way the "two sovereigns" theory reinforces the concern that the availability of accommodations can corrupt religion. As Koppelman shows, the concern that accommodations corrupt religion can be developed out of a number of faith traditions. ${ }^{142}$ The view taken here of the "two sovereigns" theory is less ecumenical, particularly in its rather strong position that the two sovereigns are opposed to each other in principle and not merely occasionally in practice, but it is connected to some faith traditions, and in that sense is fairly described as pro-religion for purposes of pro-religion strict separation.

\section{Third-Party Effects on Other Religious Persons}

Finally, I note that accommodations sincerely sought by some can have substantial adverse effects on others. ${ }^{143}$ The current law of accommodations makes third-party effects relevant to the question of whether there are less restrictive methods of advancing the government's interest than a system at 5 .

${ }^{140}$ Perry Dane, Letter to the Editor, Competing Ethics, New Yorker, June 23, 2014,

${ }^{141}$ Records of the Governor and Company of the Massachusetts Bay in New England (1853), II: 203.

${ }^{142}$ For Koppelman's discussion of some faith traditions, see Koppelman, supra note 121, at 1854-57 (discussing Roger Williams); id. at 1860-61 (discussing Samuel Pufendorf); $i d$. at 1864-66 (discussing Isaac Backus). Koppelman himself does not use these faith traditions to support an argument against accommodations. I refer to his work only for the purpose of showing that various faith traditions are concerned with the problem of corruption through interactions between government and religion.

${ }^{143}$ The problem of sect preference in the actual administration of a regime of targeted accommodations (see supra text accompanying notes 73-78) could be characterized as a problem of such third-party effects, but it is not my focus here. 
without accommodation or with limited accommodations. ${ }^{144}$ So, for example, in Hobby Lobby opponents of the accommodation emphasized that allowing it would impose unjustifiable burdens on women who wanted to use the contraceptive methods Hobby Lobby thought were methods of abortion. ${ }^{145}$ The Court acknowledged the relevance of this concern indirectly in stating that there were mechanisms of accommodating Hobby Lobby's belief such that the "effect . . . on the women employed by Hobby Lobby . . . would be precisely zero." 146

Here, my concern is different. To claim an accommodation under the Religious Freedom Restoration Act, one must assert that the government program at issue places a substantial burden on religious conscience. ${ }^{147}$ Courts are almost certainly going to accept a claimant's assertion that the burden is substantial; to do otherwise would put the courts in the position of assessing the merits of the religious claim, as Justice Scalia suggested in Smith. ${ }^{148}$ Once again, religious pluralism matters. In a religiously pluralist society, for any government program, somebody is going to sincerely assert that the program substantially burdens his or her religious conscience. And, for many supporters of the government program - and for many not embedded in the particular faith tradition being invoked-the claim of substantial burden will ring hollow. To revert to an earlier example, many secularists, supporters of the Affordable Care Act, supporters of the right to choose with respect to contraception, and others will be incredulous at the claim that filling out a form claiming an exemption substantially burdens religious conscience, and even more so in the posited next phase of litigation, where merely informing the government of one's objections will be said to burden conscience. The political reaction to Hobby Lobby, coming primarily from politicians seeking to identify themselves with women's rights, the women's rights movement itself, and LGBT activists would probably recur, perhaps even more forcefully. ${ }^{149}$

${ }^{144}$ Cf. Hobby Lobby, 134 S. Ct. at 2781 n.37 ("It is certainly true that in applying RFRA 'courts must take adequate account of the burdens a requested accommodation may impose on nonbeneficiaries.' That consideration will often inform the analysis of the Government's compelling interest and the availability of a less restrictive means of advancing that interest." (quoting Cutter v. Wilkinson, 544 U. S. 709, 720 (2005))).

${ }^{145}$ Id. at 2799-800 (Ginsburg, J., dissenting).

${ }^{146} I d$. at 2760.

${ }^{147}$ Although I believe that proponents of targeted accommodations are likely to use similar language in their advocacy, I am uncertain about whether or how the concerns I develop in the text would arise in that setting.

${ }^{148}$ Emp't Div. v. Smith, 494 U.S. 872, 886-87 (1990) ("It is no more appropriate for judges to determine the 'centrality' of religious beliefs . . . than it would be for them to determine the 'importance' of ideas ... in the free speech field.").

${ }^{149}$ For an early discussion of that reaction, see David Firestone, The Political Repercussions of the Hobby Lobby Decision, N.Y. Times, Taking Note: The Editorial Page EDITOR's BLOG (June 30, 2014), http://takingnote.blogs.nytimes.com/2014/06/30/the-poli tical-repercussions-of-the-hobby-lobby-decision, archived at http://perma.cc/NLA3-Y2 82. 
The effect of all this is to discredit religion as such among large segments of the national community. Nor, of course, will those with these sincere religious objections recede from them simply because of the effects of their claims on public views about religion as such: they are not adherents of "religion" in some generic sense, but adherents of their own religion, which counsels them to refrain from cooperating with evil as they understand cooperation. But, for those interested in religion in a pluralist society, the adverse effect of what many will describe as extreme claims on religion in general is a matter of concern. A regime of strict separation that does not allow for accommodations is, for that group, pro-religion.

\section{B. Pro-Religion Strict Separation and an Alternative Mode of Protecting Religious Practices}

I think it worth noting that pro-religion strict separation does not mean that religious practices go without constitutional protection, only that they are not protected because they are religious. ${ }^{150}$ They can receive protection because they are exercises of what I awkwardly call a general right to liberty. ${ }^{151}$

Goldman v. Weinberger ${ }^{152}$ can illustrate this point. Suppose we treat the right to wear headgear of one's choice as an aspect of the general right to liberty. Intrusions on that right have to be justified, and more than mere rationality ought to be required: the State should be required to show that what it gains from uniformity in military wear is sufficient to justify the intrusion on Goldman's general right to liberty. ${ }^{153}$

${ }^{150}$ There is now a mildly interesting academic literature on whether religion deserves protection as such, or as a subset of a broader category of conscience. Compare Micah Schwartzman, What If Religion Is Not Special?, 79 U. CHI. L. Rev. 1351 (2012) (taking the latter position), with Andrew Koppelman, Religion's Specialized Specialness, 79 U. Chi. L. Rev. Dialogue 71 (2013) (taking the former). The position taken in this Article is even less focused on religion than the "conscience-protecting" position, but, as I hope is clear, that does not mean that it regards religious belief and practice as "merely" an aspect of general liberty in some ontological sense. Pro-religion strict separation is a claim about how religion is best treated in law.

${ }^{151}$ The general right to liberty is a constitutionalized version of the maxim about liberty in Great Britain: there, everything is permitted except that which is prohibited by act of Parliament. See Malone v. Comm'r of Police (No 2), [1979] 2 All E.R. 620 (Ch.) at 630. ("England, it may be said, is not a country where everything is forbidden except what is expressly permitted: it is a country where everything is permitted except what is expressly forbidden.”).

152475 U.S. 503 (1986). Another case often used to illustrate the need for religious liberty protection beyond general liberty is Menora v. Illinois High School Ass'n, 683 F.2d 1030 (7th Cir. 1982), a pre-Smith decision discussing accommodations that would allow a high school basketball player to play despite a general regulation prohibiting wearing "hats or other headgear," including yarmulkes. The "general right to liberty" position would require that the State show rather than merely contend that barring religious headgear in high school basketball games promotes interests in safety.

${ }^{153}$ To be clear, this is a general right to liberty, applicable to choices about how to make a living as much as it is to choices about what religious headgear to wear. The test I would apply is a modest uptick from the mere rationality standard applied today to regu- 
As Kurland understood, singling out religion for distinctive treatmentdeparting from strict facial neutrality - poses threats to religion itself, even when those threats come covered with the velvet glove of accommodations. The risk of corruption in several forms and the diminution of general respect for religion when some see accommodation claims as disingenuous or extravagant are matters that should concern friends of religion. Decision makers interested in preserving vigorous religious commitments in a religiously pluralist society should resist the plea that a "decent modesty" counsels in favor of accommodating religious belief within general regulatory programs.

\section{Conclusion}

Michael McConnell's identification of a principle of accommodation of religion that could be deployed across a wide range of doctrinal areas transformed our understanding of the Religion Clauses. In 1985, students of those clauses focused on whether we could reach some sort of general agreement or overlapping consensus about the role of religion in public life using ideas developed in connection with classical establishments of religion. The debate was over whether any one view-whether a denominational view, a view favoring religion in general, or a secularist view-could do the job. The idea of accommodation seemed for a generation or so to provide a route out of the difficulties the field faced.

Contemporary controversies suggest that it can no longer serve as a master concept for the field. ${ }^{154}$ The politics surrounding religion in a religious pluralist society probably make the general issue intractable. As controversies over the Hobby Lobby decision and proposals to accommodate religious concerns with respect to women's abortion rights, marriage equality, and other modern equality agenda rights show, the issue of accommodations has now become bound up with much broader developments in the nation's political culture. I think it is probably a mistake to think that the question of accommodation of religion can now be answered satisfactorily without equally satisfactory — and at the moment unavailable-answers to all the questions raised by modern culture wars.

Rather than reaching for some overarching theory to order the field, we might be better off returning to one strand of the academic tradition that McConnell transformed: attempting to reach discrete agreements about narrowly defined problems. Questions about school vouchers would be seen as different from questions about direct financial aid to religiously affiliated schools, for example, with the possible outcome that some systems of school

lations affecting the right to pursue an occupation, but it is not Lochner v. New York, 198 U.S. 45 (1905), revived. I hope to provide a more complete discussion of the argument about the general right to liberty elsewhere.

${ }^{154}$ A regime of permissible targeted accommodations might not produce as many of the difficulties I have discussed in the Article, although my current, underdeveloped view is that the difficulties could not be entirely avoided. 
vouchers and some systems of direct aid would be permitted and some would not. Yet, such a course would almost certainly revive criticisms of religion clause doctrine for incoherence. The rise of "constitutional theory" over the past generations, with its quest for unified accounts of "the Constitution," ${ }^{155}$ suggests that scaling back the claims of doctrinal analysis will be quite difficult. ${ }^{156}$

${ }^{155}$ For a critique of constitutional theory along these lines, by a judge conventionally described as conservative see generally J. HaRvie WiLkinson III, Cosmic Constitutional Theory: Why Americans Are Losing Their Inalienable Right to SelfGovernance (Geoffrey R. Stone ed., 2012).

${ }^{156} \mathrm{Cf}$. Steven D. Smith, Discourse in the Dust: The Twilight of Religious Freedom?, 122 HaRv. L. REv. 1869 (2009) (book review) (criticizing the work of Kent Greenawalt for making what I take to be discrete judgments about how the complex values implicated in Religion Clause controversies can be sorted out on a problem-by-problem basis). But see David A. Strauss, The Living Constitution 33-49 (2010) (defending what Strauss calls a "common law" method of resolving constitutional questions). 
